\title{
Effects of environmental features and sport hunting on caribou migration in northwestern Alaska
}

\author{
Timothy J. Fullman ${ }^{1 *}$, Kyle Joly ${ }^{2}$ and Andrew Ackerman ${ }^{3}$
}

\begin{abstract}
Background: Ungulate movements are influenced by a variety of biotic and abiotic factors, which may affect connectivity between key resource areas and seasonal ranges. In northwestern Alaska, one important question regarding human impacts on ungulate movement involves caribou (Rangifer tarandus) response to autumn hunting and related aircraft activity. While concerns have been voiced by local hunters about the influence of transporter aircraft and nonlocal sport hunters, there has been little quantitative analysis of the effects of hunter activity on caribou movement. We utilized a novel spatial dataset of commercial aircraft landing locations and sport hunter camps in and around Noatak National Preserve to analyze resource selection of caribou in autumn for non-local hunting activity and environmental features. We combined step selection functions with randomized shortest paths to investigate whether terrain ruggedness, river width, land cover, and hunting activity (in the form of aircraft landings and sport hunter camps) facilitated or impeded caribou movement. By varying a parameter in the randomized shortest path models, we also explored the tradeoff between exploration and exploitation in movement behavior exhibited by traveling caribou.

Results: We found that caribou avoided rugged terrain and areas with more river, forest, and tall shrubs while selecting for areas dominated by tussock tundra and dwarf shrubs. Migration of caribou through Noatak does not appear to be inhibited by sport hunting activity, though this does not preclude the possibility of temporary effects altering availability of caribou for individual hunters. Caribou exhibited exploratory movement, following predictions of a random walk model. This behavior may facilitate the location of remaining patches of high-quality forage prior to the onset of winter, especially during mild autumns.

Conclusions: Understanding animal movement behavior is fundamental to protecting critical areas of connectivity and to informing management decisions. Our study identifies migratory connectivity and hotspots of potential conflict among user groups, enabling development of policies that balance human access with species conservation.
\end{abstract}

Keywords: Aircraft, Alaska, Caribou, Hunting, Migration, Movement, Noatak National Preserve, Rangifer tarandus, Resource selection

\section{Background}

Animal movement is a key ecological process [1-3] that influences population dynamics $[4,5]$, predator-prey interactions $[6,7]$, gene flow $[8,9]$, use of dynamic resources [10], and vulnerability to environmental change [11-13]. In light of extensive and increasing human alteration of natural areas, maintaining connectivity across landscapes is important to facilitate species movement and retain the

\footnotetext{
* Correspondence: tim_fullman@tws.org

1The Wilderness Society, 705 Christensen Drive, Anchorage, AK 99501, USA

Full list of author information is available at the end of the article
}

associated processes [14-16]. A strong understanding of animal movement behavior plays a critical role in assessing connectivity, as well as how environmental changes might enhance or reduce connectivity [17].

Studies of animal movement and connectivity are increasingly being used to inform management decisions $[18,19]$. Resource managers are often tasked with conserving species and maintaining habitat while balancing the interests of multiple user groups. This is an inherently spatiotemporal process that involves choices about where, when, and how access should be given versus restricted to meet management objectives. The importance of 
protected areas in helping maintain connectivity for wildlife [20-22] makes it critical that such decisions do not unduly compromise the ability of species to move through managed areas.

In northern Alaska, caribou (Rangifer tarandus) form an iconic part of the landscape, migrating thousands of kilometers each year in one of the longest terrestrial migrations in North America [23, 24]. Caribou migrate north in the spring to calve in the northern foothills of the Brooks Range [25, 26]. In autumn, most caribou migrate south to winter in areas with greater cover and winter food availability $[27,28]$. As the most abundant large herbivores in the Arctic [29], caribou are an important food resource for a variety of predator species [30-33] as well as local communities [34-36]. Non-local sport hunters also harvest caribou in the region [37]. Balancing the subsistence needs of local hunters with the responsibility to provide hunting opportunities for non-local hunters can be a difficult task for managers. In some areas, local hunters have come into conflict with non-local hunters seeking caribou [38, 39]. Though the documented impacts typically have been relatively minor and of short duration (e.g., [40, 41]), local hunters perceive that non-local hunting and the associated aircraft activity have changed the migratory patterns of caribou [42]. Agencies tasked with managing wildlife species and human access to protected areas need additional information regarding critical movement routes of subsistence species like caribou, as well as an increased understanding of animal response to human activity to identify "hotspots" of potential conflict among user groups.

We investigate movement patterns of caribou in response to non-local sport hunting and environmental features in Noatak National Preserve, Alaska (hereafter, Noatak). Caribou have been hunted in Noatak for thousands of years by local indigenous people. Sport hunting in and around Noatak has occurred for decades but appears to have increased markedly since 2000 [37]. Local hunters primarily access Noatak using boats along the Noatak River, while sport hunters typically use small, commercially-operated transporter aircraft [37]. Conflict between the two groups arose early in Noatak's history over competition for caribou and other species and the perceived negative effects of aircraft noise by local hunters [39]. Similar concerns continue to be voiced today [42, 43]. In response to concerns about user conflict, federal land managers established a delayed entry area for non-local hunters in the western portion of Noatak to provide increased opportunities for undisturbed hunting by local subsistence hunters. In 2016, faced with continued reports of user conflict and declining population size of the caribou herd using Noatak, the Federal Subsistence Board closed Noatak and other federal public lands to sport hunters seeking to harvest caribou.
The purpose of this study is to investigate how a suite of factors, especially sport hunting activity, affect caribou movement patterns through Noatak. An increased understanding of whether the ability of caribou to pass through Noatak during their autumn migration is altered by sport hunting activity can be used to help inform decisions by land management agencies, such as continuation of public lands closures for certain user groups like caribou sport hunters. We use caribou GPS telemetry data and datasets of sport hunter camps and aircraft landing sites over a period of four hunting seasons to evaluate the hypothesis that sport hunting activity influences habitat selection of caribou migrating through Noatak against the null hypothesis of no impact.

In addition to exploring the influence of sport hunting activity on caribou movement, we test how observed caribou movement patterns correspond to a range of possible movement behaviors. Common techniques for assessing movement routes and connectivity of wildlife species, such as least cost path [44] and circuit theory [45] models, have contributed to understanding of connectivity [46-49], but have at times been criticized for making unrealistic movement assumptions [50-53]. Further empirical evidence is needed of how animal movement behavior coincides with different movement strategies to inform model choice for connectivity studies [51, 54]. We use the step selection function randomized shortest path (SSF-RSP) approach [53] to identify whether caribou movement behavior most closely fits a random walk movement pattern (in line with circuit theory), an optimal movement strategy (in line with least cost paths), or an intermediate strategy that mixes the two. The results of these analyses can help inform future connectivity modeling work as well as providing specific information to Alaskan managers seeking to balance hunter access from different user groups with species conservation.

\section{Methods \\ Study area}

Noatak spans approximately 2.7 million hectares in northwestern Alaska (Fig. 1). Along with neighboring Gates of the Arctic National Park and Preserve, Noatak protects the watershed of the Noatak River, the longest free-flowing wild river in the United States [55]. Noatak is used by caribou of the Western Arctic Caribou Herd (WACH) throughout the year, and especially during their spring and autumn migrations when they pass through Noatak on their way to the calving grounds and winter range, respectively [24, 28]. Caribou are a key species of management concern in Noatak [55], with a focus on maintaining both healthy ecological conditions for caribou and a sustainable population for local subsistence hunters. The WACH currently numbers around 201,000 individuals [56] and has been in decline since the early 2000s 


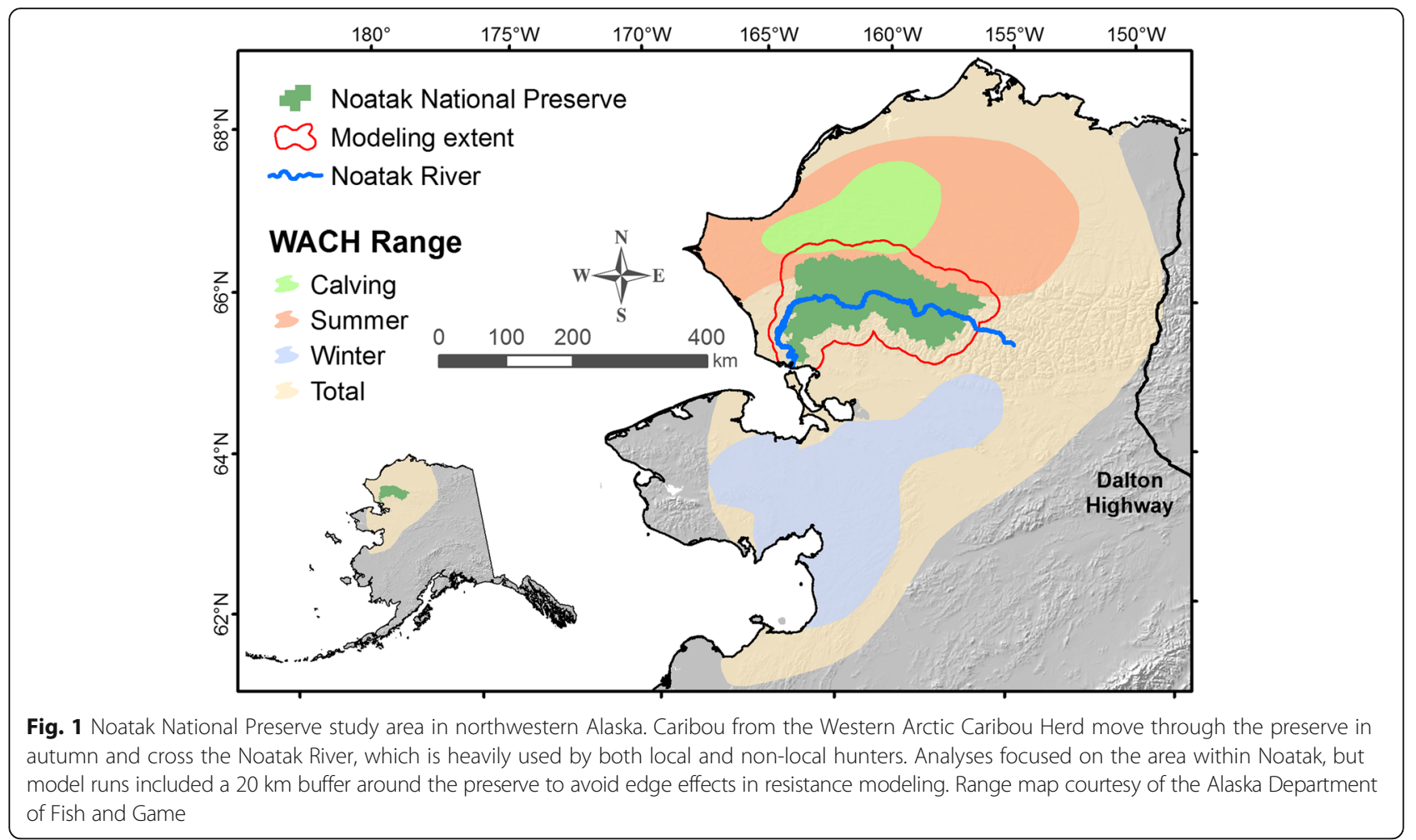

[28]. Approximately 12,000 caribou are harvested from the WACH each year, with about $5 \%$ of this harvest occurring by non-local hunters [57].

While Noatak comprises the primary study area, a "modeling extent" consisting of a $20 \mathrm{~km}$ buffer around Noatak, clipped where it extends into the ocean (Fig. 1), is analyzed to avoid artificial boundary effects on estimates of landscape resistance and connectivity within Noatak $[48,58]$. Koen et al. [48] recommend a buffer of approximately $20 \%$ of the study area width to remove the effects of node placement on current density. A $20 \mathrm{~km}$ buffer represents approximately $20 \%$ of the height of Noatak and $10 \%$ of the width and was chosen as a compromise between including a larger buffer and only including areas for which sport hunter usage data were available.

\section{Caribou telemetry data}

Locations of 55 adult female caribou from the WACH were recorded using GPS telemetry data collected from 2010 to 2013. Caribou swimming across the Kobuk River at Onion Portage were restrained by hand and fitted with GPS telemetry collars programmed to record one location every eight hours [59]. Collars provided between one and four years of information (median $=2$ years). Animal handling was approved by the State of Alaska's Animal Care and Use Committee (ACUC) protocol \#2012-031R.

Caribou data falling within the modeling extent were extracted for the autumn period (August $1^{\text {st }}$ to November $\left.30^{\text {th }}\right)$, corresponding with the primary migration and nonlocal hunting seasons. The resulting telemetry dataset contained 7006 total steps (pairs of locations). Steps with missing data (i.e., time intervals longer than eight hours) and those that had any part extending beyond the modeling extent were removed from the dataset. This resulted in 6596 steps over the 4-year period (94.2\% of the original data).

\section{Environmental covariate data}

Hunting activity data consisted of commercial aircraft transporter landing sites (remote, unmaintained strips used to get sport hunters in and out of Noatak) and sport hunter camps. Non-local hunters that utilized Noatak between 2010 and 2013 were asked to fill out a voluntary mail-back survey indicating the year and location of hunting camps they used [37]. Locations were converted to a spatial point dataset using ArcGIS (version 10.3, ESRI, Redlands, CA). Locations were only retained for hunting parties that spent at least $24 \mathrm{~h}$ within the modeling extent. Data on commercial transport aircraft landing events (locations and dates) were compiled from existing State of Alaska Big Game Commercial Services Board-Licensed Transporter Aircraft records and converted to a spatial point dataset in ArcGIS. Locations from the hunter camp and transporter landing datasets were clipped to the modeling extent and filtered to only include records occurring during the study period. 
Predators, including human hunters, do not have to be physically present to affect the behavior and space use of prey species [60,61]. This may lead to avoidance of areas easily accessible to hunters as a strategy to reduce predation risk [62]. To represent the general pattern of relative intensity of hunting activity to which caribou may be responding, a utilization distribution of hunting activity locations across the study period was created $[63,64]$. The hunter camp and transporter landing datasets were combined into a single hunting activity layer for creation of the utilization distribution to account for spatial and temporal differences between the datasets and spatial autocorrelation. Hunter camp records indicated the year but not the specific date a camp was used. Because hunters were asked to report only the camp locations from their most recent trip, records were biased toward later years (number of camps in $2010=24,2011=$ 78, $2012=94,2013=219)$. Transporter records were mixed, with some indicating the specific date of landing and others only the year. These locations were more evenly distributed over the study period (number of landings in $2010=140,2011=190,2012=216,2013=152$ ). Most hunters established camps near their drop-off locations (within $0.5 \mathrm{~km}$ ) for the duration of their hunting trip, leading to a strong correlation between the transporter landing and hunter camp datasets. In addition, many hunters hunt on the day they are dropped off by the transporter. The utilization distribution on the combined dataset was created in $\mathrm{R}$ [65] at a $120 \mathrm{~m}$ spatial resolution using the adehabitatHR package [66] with the ad hoc approach of Kie [67] used to select the optimal bandwidth.

Other environmental variables included terrain ruggedness, river area, and land cover. While more rugged areas likely increase energetic costs for movement through climbing slopes [68] and greater movement tortuosity [69], previous studies have shown selection for more varied topography by caribou $[59,70]$, likely due to increased forage availability [71, 72]. Terrain ruggedness was calculated using the vector ruggedness measure, which measures vector dispersion on a digital elevation model (DEM) to take into account heterogeneity in both slope and aspect [73]. A 120 m DEM was derived from the National Elevation Dataset (NED; [74]). The $60 \mathrm{~m}$ NED elevation raster was resampled to a $120 \mathrm{~m}$ spatial resolution using cubic convolution. Terrain ruggedness was calculated on the $120 \mathrm{~m}$ resolution DEM in ArcGIS using the Vector Ruggedness Measure Tool [75] with a $3 \times 3$-pixel window. Williams and Gunn [76] investigated water crossings used by caribou in Canada and found river width appeared to influence crossing location, with caribou crossing more frequently in narrow areas. The percentage of a $120 \mathrm{~m}$ pixel consisting of river was used as a continuous raster representation of river width. River areas per pixel were calculated from the NHDArea polygons of the National Hydrography Dataset [77]. Land cover type was derived from a composite map of Alaska vegetation [78] and was grouped into eight classes: dwarf shrub, forest, tussock tundra, herbaceous, tall shrub, low shrub, lichen, and water. The water class was predominantly composed of lakes within the study area and only exhibited a $5.2 \%$ overlap with the river layer described above. The $30 \mathrm{~m}$ land cover data were resampled to a $120 \mathrm{~m}$ spatial resolution in ArcGIS using a majority filter. For maps and ranges of the input covariates see Additional file 1: Figure S1.

When resampling covariate data, the modifiable areal unit problem (MAUP) may be an issue, potentially affecting results based on the effect of changing spatial resolution rather than based on the ecological process of interest [79]. Unfortunately, there currently is a lack of reliable approaches to identify whether artifacts are introduced when working with real-world data [80]. In such situations, however, resampling may be necessary when combining disparate datasets with varying native resolutions to provide a uniform scale for resistance surface creation. Further constraints on resolution may be presented by analytical issues such as maintaining computational feasibility for connectivity models. Fortunately, some connectivity approaches appear to be robust to altering resistance surface resolution (e.g., [45]).

\section{Statistical analysis}

Caribou movement was analyzed following the step selection function randomized shortest path (SSF-RSP) approach of Panzacchi et al. [53]. The SSF-RSP approach first uses step selection function (SSF) models to estimate resistance to movement from environmental variables. Following Panzacchi et al. [53], we used conditional logistic regression to compare the environmental covariates for each observed caribou step against ten randomly generated "available" steps. How availability data are defined in such studies can strongly influence findings [81]. Lengths of random steps were chosen using a uniform distribution with a maximum corresponding to the $99^{\text {th }}$ percentile of the observed step length distribution to avoid inclusion of too many points close to the starting location [53, 82]. Continuous variables (e.g., terrain ruggedness, hunting activity) were recorded as the maximum value along a step [53]. Since the goal was to estimate resistance to movement, the maximum value was used to represent the limiting value of a given variable along a movement step. Categorical land cover classes were also represented in a continuous manner as the proportion of each land cover class along a step. Step lengths were included in the conditional logistic regression model to reduce bias in model coefficients [83] and were adjusted for elevation to better reflect the total distance travelled in a step [53]. Covariates were standardized by dividing by twice their 
standard deviation [84]. Analysis of variance inflation factors showed collinearity was not an issue (all VIF values < 3; $[85,86])$, so a set of candidate SSF models was built using a factorial combination of environmental covariates (Table 1). All models contained a spline of the elevation-adjusted step length, included using the pspline function in the survival package $[87,88]$ with two degrees of freedom, following Panzacchi et al. [53].

Conditional logistic regression (CLR) models were run using the survival package and model selection was performed using Akaike's Information Criterion corrected for small sample size (AICc; [89]). Robust standard errors controlling for multiple observations per individual were calculated following the approach of Forester et al. [83]. In brief, this consisted of fitting an intercept-only mixed-effects model to the deviance residuals of the top SSF model, with a random intercept included for individual caribou. The lag of correlation was identified using an autocorrelation function on the mixed-effects model results and was used to assign the original data into independent clusters. The data were subset into two independent groups using the clusters and a CLR model was fit on each subset. The resulting covariance matrices from each subset were then averaged to provide adjusted standard errors. Predictive performance of the final model was evaluated using k-fold cross validation [90, 91] with ten folds.

Table 1 Candidate models for caribou resource selection in Noatak National Preserve, Alaska

\begin{tabular}{ll}
\hline Model number & Model \\
\hline 0 & Null \\
1 & Rugged \\
2 & Hunting \\
3 & River \\
4 & LandCover \\
5 & Rugged + Hunting \\
6 & Rugged + River \\
7 & Rugged + LandCover \\
8 & Hunting + River \\
9 & Hunting + LandCover \\
10 & River + LandCover \\
11 & Rugged + Hunting + LandCover \\
12 & Rugged + Hunting + River \\
13 & Rugged + River + LandCover \\
14 & Hunting + River + LandCover \\
15 & Rugged + Hunting + River + LandCover \\
\hline
\end{tabular}

Covariates considered included terrain ruggedness (Rugged), sport hunting activity (Hunting), river area (River) and land cover type (LandCover). LandCover consisted of seven parameters, representing the proportion of each land cover type. In addition, each candidate model included a spline of the distance to previous used location to help reduce bias in step selection function estimation
The final model from the SSF analysis was used to predict movement friction (1/relative suitability) across the study area. This friction map was then input into a randomized shortest path (RSP) model to predict the presence of corridors and barriers across the landscape under various movement strategies [53]. The RSP model estimated the expected number of passages of animals moving between two areas under different movement strategies [53]. Movement strategies were controlled by a parameter, $\theta$, that influenced how strongly the modeled animals tended between a random walk movement model (habitat exploration) and a least cost path movement model (habitat exploitation; for details see [53]). Multiple RSP models were run, testing different values for $\theta$ to reflect varying tradeoffs between exploration and exploitation. Seven $\theta$ values were modelled: $0,1 \mathrm{e}-6,1 \mathrm{e}-5,1 \mathrm{e}-4$, $1 \mathrm{e}-3,1 \mathrm{e}-2,1 \mathrm{e}-1$. The endpoints represented random walk (exploratory) and least cost path (exploitative) movement, respectively, while the intermediate values represented a mix between the two approaches. For each $\theta$ value 100 random pairs of points were generated with one point in the northern half of the $20 \mathrm{~km}$ buffer around Noatak and the other point in the southern half of the buffer. An RSP model was run for each pair and the resulting maps were summed to yield an overall estimate of number of visits per pixel across the 100 pairs. R code to run the SSF and RSP models was adapted from Panzacchi et al. [53]. RSP analyses were run for the full modeling extent and resulting maps were clipped to the Noatak boundary study area to remove edge effects from the modeling process.

The best fitting RSP $\theta$ value was selected as the one that minimized the mean squared error (MSE) between the RSP model and observed caribou corridors represented by a Brownian bridge movement model (BBMM; [53]). A BBMM was created using the BBMM package in $\mathrm{R}$ [92], which follows the general approach of Horne et al. [93] and Sawyer et al. [94]. Location error in the BBMM model was parameterized as $33 \mathrm{~m}$ [95]. RSP outputs and BBMM maps were standardized to sum to one before MSE calculation [53]. The summed map from the RSP models with the best-fitting $\theta$ value provided a population-level representation of relative suitability for migration across the study area.

\section{Results}

Model selection indicated two models had $\triangle \mathrm{AICc}$ values of less than 2 (Table 2). As Burnham and Anderson [89] pointed out,

"Models having $\Delta_{i}$ within about $0-2$ units of the best model should be examined to see whether they differ from the best model by 1 parameter and have essentially the same values of the maximized log-likelihood as the best model. In this case, the larger model is not really 
Table 2 Model selection results for caribou resource selection in Noatak National Preserve, Alaska

\begin{tabular}{llrll}
\hline Model & \multicolumn{1}{l}{$K$} & \multicolumn{1}{l}{$\Delta$ AICc } & Akaike weight & Log-likelihood \\
\hline 13 & 16 & 0.00 & 0.62 & -11721.49 \\
15 & 17 & 0.94 & 0.38 & -11720.96 \\
7 & 15 & 16.82 & 0.00 & -11730.90 \\
11 & 16 & 17.31 & 0.00 & -11730.15 \\
10 & 15 & 85.96 & 0.00 & -11765.47 \\
14 & 16 & 87.94 & 0.00 & -11765.46 \\
4 & 14 & 94.00 & 0.00 & -11770.49 \\
9 & 15 & 95.94 & 0.00 & -11770.46 \\
6 & 9 & 135.32 & 0.00 & -11796.16 \\
12 & 10 & 136.76 & 0.00 & -11795.88 \\
1 & 8 & 158.33 & 0.00 & -11808.66 \\
5 & 9 & 159.41 & 0.00 & -11808.20 \\
3 & 8 & 245.84 & 0.00 & -11852.42 \\
8 & 9 & 247.49 & 0.00 & -11852.24 \\
2 & 8 & 259.20 & 0.00 & -11859.09 \\
0 & 0 & 123552.79 & 0.00 & -73513.89 \\
\hline
\end{tabular}

Candidate models were compared using Akaike's Information Criterion adjusted for small sample size (AICC). The number of parameters retained for each model (K), difference in AICc values between models $(\triangle \mathrm{AICC})$, corresponding Akaike weights, and maximized log-likelihoods of each model are reported here. Mode numbers correspond to Table 1

supported or competitive, but rather is 'close' only because it adds 1 parameter and therefore will be within $2 \Delta_{i}$ units, even though the fit, as measured by the log-likelihood value, is not improved" (p.131).

In such cases, the additional parameter in the larger of the two models is referred to as an 'uninformative parameter' and should not be considered to be supported by model selection [96]. This was the case in our study. The top two models, Model 13 and Model 15, differed by a single parameter - hunting activity (see Table 1 for model details). The maximized log-likelihood values were very similar, differing by only 0.53 (Table 2 ). The similar log-likelihoods of the top two models and difference of a single parameter indicated that hunting activity provided an uninformative parameter in Model 15, thus leading us to follow the recommendation of Arnold [96] and discard this model. This was affirmed by investigation of the confidence intervals for hunting activity. Both the $85 \%$ (which are more compatible with use of AICc for model selection [96]) and 95\% confidence intervals for hunting activity overlapped zero. The final SSF model used in our analyses, Model 13, thus included parameters for terrain ruggedness, river area, land cover type, and elevation-adjusted step length, but not hunting activity.

Step selection analysis revealed areas with more rugged terrain and greater river area had a lower likelihood of use by migrating caribou (Table 3). Areas with a higher proportion of dwarf shrubs and tussock tundra were more likely to be used by migrating caribou, while those with a higher proportion of forest, tall shrubs, and water were more likely to be avoided. Herbaceous vegetation and areas dominated by lichens were used proportionally to their availability. Cross-validation results indicated high predictive performance for the final model (mean Spearman's correlation across folds $=0.985$ ) .

Summed RSP maps for the seven $\theta$ values covered a wide range of spatial patterns (Fig. $2 \mathrm{a}-\mathrm{g}$ ). Predicted distributions displayed by the RSP maps followed expected patterns under the movement strategies represented by the various $\theta$ values. Maps of smaller $\theta$ values featured broad areas of connectivity, reflective of spatial use under a random walk, while those for larger values of $\theta$ tended to strongly concentrate corridors into relatively straight lines, reflecting least cost movement. Intermediate $\theta$ values showed a gradient between these two patterns. Calculation of the mean squared error (MSE) between RSP maps and observed caribou corridors (Fig. 2h) identified a $\theta$ value of 0 as the best-fitting model (Table 4). This indicated that caribou passing through Noatak in autumn exhibit primarily exploratory movement, following predictions of a random walk model. Under this model, predicted caribou use was broad across the study area, but concentrated most

Table 3 Conditional logistic regression coefficients for the final model of step selection by caribou in Noatak National Preserve, Alaska

\begin{tabular}{lcl}
\hline Covariate & Coefficient & Standard Error \\
\hline Terrain ruggedness & -0.62 & 0.12 \\
River area & -0.22 & 0.08 \\
Dwarf shrub proportion & $\mathbf{0 . 1 9}$ & $\mathbf{0 . 0 8}$ \\
Forest proportion & -0.35 & 0.09 \\
Herbaceous proportion & 0.06 & 0.05 \\
Lichen proportion & -0.10 & 0.08 \\
Tall shrub proportion & -0.22 & 0.08 \\
Tussock tundra proportion & $\mathbf{0 . 1 9}$ & $\mathbf{0 . 0 9}$ \\
Water proportion & -0.11 & 0.05 \\
Step length 1 & $-\mathbf{2 . 4 3}$ & $\mathbf{0 . 1 3}$ \\
Step length 2 & $-\mathbf{4 . 6 6}$ & $\mathbf{0 . 2 3}$ \\
Step length 3 & -5.94 & $\mathbf{0 . 2 4}$ \\
Step length 4 & -5.48 & $\mathbf{0 . 3 0}$ \\
Step length 5 & $-\mathbf{4 . 1 5}$ & $\mathbf{0 . 5 4}$ \\
Step length 6 & $-\mathbf{2 . 7 0}$ & $\mathbf{0 . 8 6}$ \\
Step length 7 & -1.23 & 1.19 \\
\hline
\end{tabular}

The Step length 1-7 covariates report the coefficient values from the elevation-adjusted step length spline. Standard errors reflect Forester et al. [83]'s adjustment for serial autocorrelation. Values in bold indicate that the coefficient's $95 \%$ confidence interval does not overlap zero. Overlap patterns were identical for $85 \%$ confidence intervals (cf. Arnold [96] for use of wider confidence intervals with information theoretic model selection) 

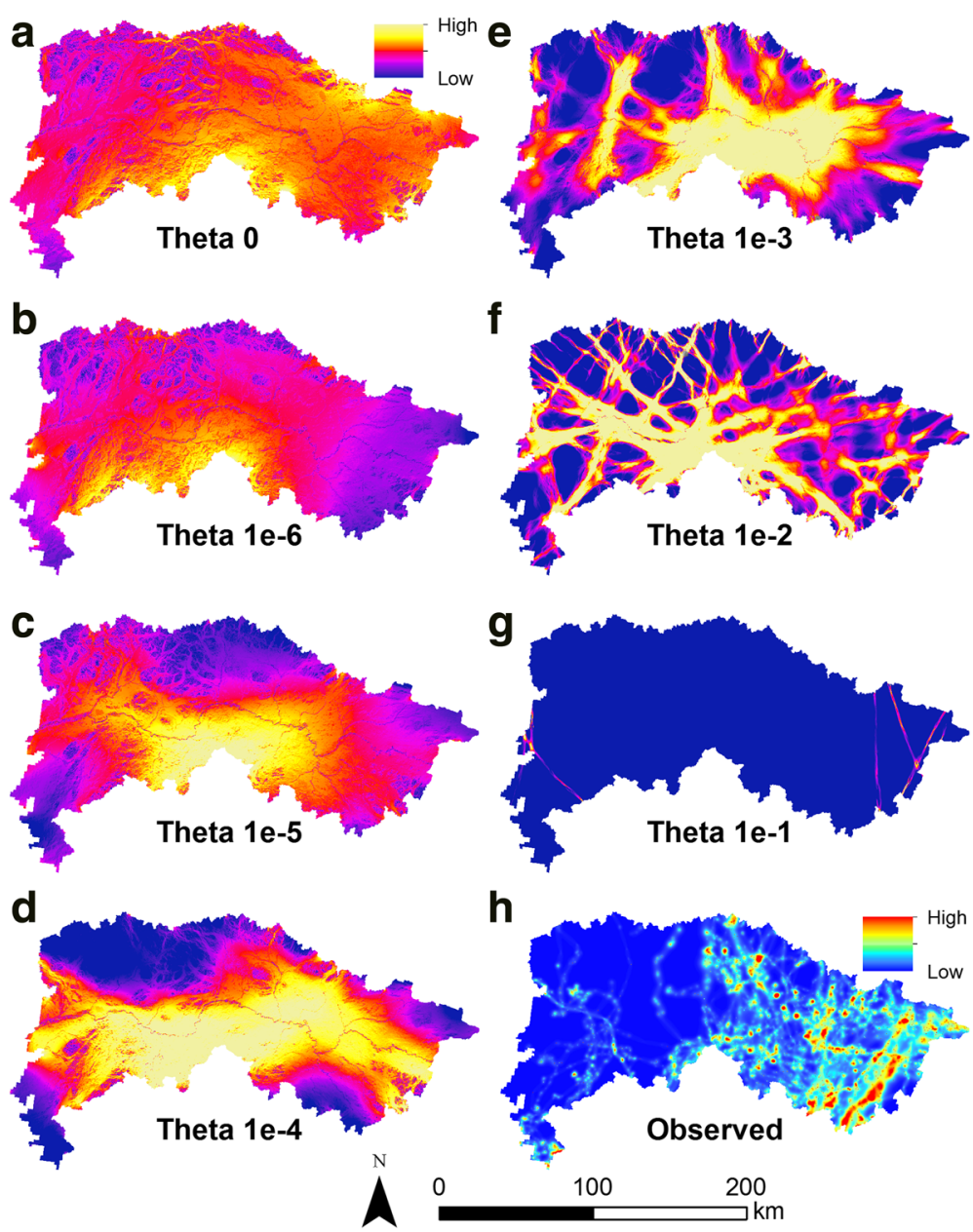

Fig. 2 Predicted and observed corridors for autumn caribou movement through Noatak National Preserve, 2010-2013. Predicted corridor maps $(\mathbf{a}-\mathbf{g})$ are the sum of 100 randomized shortest path model runs for a given $\theta$ value. Values of $\theta$ represent a range of movement strategies with $\theta=0$ reflecting random-walk style exploratory movement (a) and $\theta=0.1$ reflecting least cost path exploitative movement ( $\mathbf{g}$ ). Intermediate $\theta$ values depict a mixture between these two strategies. Observed movement corridors (h) are represented using a Brownian bridge movement model built on GPS locations of 55 adult female caribou

Table 4 Mean squared error values reflecting fit between predicted and observed movement corridors

\begin{tabular}{ll}
\hline$\theta$ value & Mean squared error \\
\hline 0 & $5.08 \times 10^{-13}$ \\
$1 \times 10^{-6}$ & $5.28 \times 10^{-13}$ \\
$1 \times 10^{-5}$ & $5.10 \times 10^{-13}$ \\
$1 \times 10^{-4}$ & $5.22 \times 10^{-13}$ \\
$1 \times 10^{-3}$ & $5.21 \times 10^{-13}$ \\
$1 \times 10^{-2}$ & $5.65 \times 10^{-13}$ \\
$1 \times 10^{-1}$ & $3.11 \times 10^{-12}$ \\
\hline
\end{tabular}

Predicted movement corridors were generated using randomized shortest paths (RSPs) for each $\theta$ value. A $\theta$ value of 0 reflects exploratory movement, similar to a random walk model, while a value of 0.1 reflects exploitative movement, similar to least cost path models. Observed movement corridors were based on a Brownian bridge movement model of caribou telemetry data. Smaller mean squared error values reflect better fit between models strongly in the central and eastern portions of Noatak and was relatively lower in the western area of the preserve (Fig. 2a; Additional file 1: Figure S2).

\section{Discussion}

Our analysis of caribou movement in Noatak National Preserve shows that caribou respond to environmental features such as terrain ruggedness and land cover type, but not to sport hunting activity at the scale considered. The negative effect of terrain ruggedness on caribou movement aligns with patterns seen for the $\mathrm{WACH}$ at the scale of the full autumn migratory path (Fullman et al., in revision), though in winter, when they are non-migratory, caribou may select for more rugged terrain [27, 70]. Similarly, our finding that caribou avoid migratory pathways with greater river area aligns with caribou crossing more frequently in narrow portions of rivers in Canada [76] and 
with increased landscape resistance to autumn migratory movement from major rivers for the WACH (Fullman et al., in revision). Patterns of vegetation influence on step selection also coincide with other reports of avoidance of dense vegetation by caribou ([70, 97], Fullman et al., in revision). Avoidance of dense vegetation may be to facilitate travel and/or to reduce predation risk.

We did not detect an effect of sport hunting activity on caribou resource selection, supporting our null hypothesis. This indicates that sport hunting does not inhibit the ability of caribou to migrate through Noatak. Local hunters have harvested caribou at key river crossing locations for 10,000 years in northwest Alaska [98]. That these locations continue to be used by caribou and local hunters to this day [24] may support our findings. Further, studies elsewhere have also found environmental factors have a greater impact on animal space use than hunting (e.g., [61, 62]). Our finding of a lack of effect of sport hunting activity on the likelihood of caribou migrating through Noatak does stand in apparent contrast to concerns voiced by local hunters regarding the negative effects of sport hunters and commercial air transporters (e.g., [39, 42, 43]). These differences may relate to issues of spatial and temporal scale. The caribou GPS locations in this study were recorded every eight hours. It is possible that caribou response to human hunting activity is shortlived, such that it is not detectable at an eight-hour interval. Experimental studies of woodland caribou response to simulated seismic exploration found that caribou respond to noise disturbance by increasing movement rates for between $15 \mathrm{~min}$ and at least two hours [99-101]. They also reported that linear displacement distances from the point of disturbance were not significantly different from control animals [100]. Such temporary responses could still have an influence for a local hunter waiting for caribou to approach, but may not affect the ability of caribou to pass through Noatak and thus not be reflected in our analysis. In addition, the lack of observed influence of sport hunting activity on caribou movement through Noatak may reflect differences in scale between the caribou telemetry dataset, which was recorded sub-daily, and the sport hunter dataset, which was aggregated across years. An aggregated representation of the general likelihood of encountering people may not reflect the fine scales at which caribou respond to and avoid hunting activity. Studies utilizing finer spatial and temporal resolution data may be needed to detect the effects described by local hunters. Furthermore, no data were available on locations of local hunting activity, so it is unclear what effect this may have had on caribou movements in areas not used by sport hunters or whether there may be additive effects. Finally, changes in the migratory routes of $\mathrm{WACH}$ caribou described by local residents [42] may be related to an industrial road that bisects the herd's migration route to the east of the study area [102]. In summary, our findings clearly indicate that sport hunting activity does not prevent caribou from migrating through Noatak, but do not address possible impacts of sport hunting disrupting individual subsistence hunting attempts at fine spatial and temporal scales.

In addition to movement responses to environmental covariates, the SSF-RSP approach also provides information on the movement strategy used by caribou in crossing through Noatak. Comparison of predicted and observed movement corridors indicates that caribou moving through Noatak are employing random walk movement behavior. This is in contrast to reindeer in Norway, which appear to follow a mixed movement strategy intermediate between random walk and least cost path movement patterns [53]. One possible explanation for the adoption of exploratory movement behavior we observed is recent patterns of mild, long autumn seasons and relatively warm winters during the study period [103]. The body mass of female caribou has a strong influence on the likelihood of successfully giving birth, timing of birthing, birth mass of calves, and offspring survival [101, 104, 105]. In elk, females that consistently select the highest quality forage available in the autumn enter winter in better condition than other individuals [106]. Mild autumn and winter conditions may allow caribou in northwestern Alaska to adopt a similar strategy, employing predominantly exploratory movement behavior to capitalize on available resources and improve body condition prior to winter. The Arctic has been warming recently [107, 108], with temperature increases most pronounced in the winter [109]. If these trends continue, mild conditions during autumn migration may become more common, reinforcing the effectiveness of an exploratory movement strategy for caribou seeking to improve body condition prior to winter.

Although not tested in this study, it is possible that our observation of exploratory movement behavior for female caribou passing through Noatak is season-specific. Female caribou migrate to the calving grounds quickly in the spring, while males lag behind to forage on new growth [59, 110, 111]. Rapid migration by pregnant females in the spring may encourage exploitative movement behavior with straighter movement paths, such as are expected with a least cost path approach. Indeed, Bergman et al. [112] observed straightened movement paths during migration to calving grounds in Canadian caribou. The mixed movement strategies reported for reindeer in Norway were observed during spring migration [53], which might contribute to the different pattern observed in our study. McClure et al. [54] found that different modeling strategies (circuit theory versus least cost paths) may be more applicable for certain types of movement than others (e.g., migration versus dispersal) and thus that the 
modeling approach should be selected based on the movement ecology of the focal species of interest. We suggest that this may be true even within a movement process based on sex- or season-specific influences on motivators and constraints of movement. Comparative studies are needed that explore this possibility more thoroughly.

\section{Conclusions}

Understanding animal movement behavior is fundamental to protecting critical areas of connectivity and to informing management decisions. We use step selection functions and randomized shortest paths to investigate how female caribou moving through Noatak respond to nonlocal hunting activity, terrain ruggedness, rivers, and land cover. Our results indicate that non-local hunting activity does not appear to affect the ability of caribou to pass through Noatak, though this does not preclude the possibility of fine-scale or temporary effects altering availability of caribou for local hunters. In addition, we found that caribou moving through Noatak employ random walk movement behavior. Such exploratory movements may reflect a behavioral response taking advantage of recent mild autumn and early winter conditions to increase body condition prior to winter, improving the likelihood of successful reproduction. Our findings have direct and immediate management implications as federal public lands in Alaska, including Noatak, have been closed to sport hunters seeking to harvest caribou due in large part to local perception that these users were negatively impacting caribou migration. The closure follows the implementation of a delayed entry area for non-local hunters in Noatak that failed to resolve user conflicts in this conservation unit.

\section{Additional file}

Additional file 1: Figure S1. Input covariate data for analyzing step selection by caribou in Noatak National Preserve, Alaska. Figure S2. Best-fitting connectivity map for caribou in Noatak National Preserve, Alaska. (PDF $540 \mathrm{~kb}$ )

\section{Acknowledgements}

Caribou captures were a collaborative effort involving the Alaska Department of Fish and Game, National Park Service, Bureau of Land Management, U.S. Fish and Wildlife Service, and regional high schools. We thank Pete Fix for helping conduct the transporter and sport hunter surveys. Comments from J. Rasic and several anonymous reviewers improved this manuscript. Use of any trade names in this manuscript does not imply endorsement by the U.S. Government.

\section{Funding}

Support for TJF was provided by a grant from the Wilburforce Foundation. The funders had no role in study design, data collection and analysis, nor manuscript writing.

\section{Availability of data and materials}

The datasets analyzed during the current study are available upon reasonable request. Please contact Kyle Joly, National Park Service, Gates of the Arctic
National Park and Preserve, Arctic Inventory and Monitoring Network via email to kyle_joly@nps.gov.

\section{Authors' contributions}

TJF and KJ conceived and designed the study. KJ collected caribou GPS locations. AA conducted hunter surveys and compiled commercial transporter locations. TJF analyzed the data. TJF, KJ, and AA wrote the manuscript. All authors read and approved the final manuscript.

\section{Competing interests}

The authors declare that they have no competing interests.

\section{Consent for publication}

Not applicable.

\section{Ethics approval and consent to participate}

Collaring of caribou was approved by the State of Alaska's Animal Care and Use Committee (ACUC) protocol \#2012-031R. Hunter surveys were approved by the University of Alaska Fairbanks Office of Research Integrity, OMB Approval Number 1024-0224.

\section{Author details}

${ }^{1}$ The Wilderness Society, 705 Christensen Drive, Anchorage, AK 99501, USA. ${ }^{2}$ National Park Service, Gates of the Arctic National Park and Preserve, Arctic Inventory and Monitoring Network, 4175 Geist Rd., Fairbanks, AK 99709, USA. ${ }^{3}$ National Park Service, Western Arctic National Parklands, 4175 Geist Rd., Fairbanks, AK 99709, USA.

Received: 25 October 2016 Accepted: 2 February 2017

Published online: 01 March 2017

\section{References}

1. Nathan R, Getz WM, Revilla E, Holyoak M, Kadmon R, Saltz D, Smouse PE. A movement ecology paradigm for unifying organismal movement research. Proc Natl Acad Sci U S A. 2008;105:19052-9.

2. Holyoak M, Casagrandi R, Nathan R, Revilla E, Spiegel O. Trends and missing parts in the study of movement ecology. Proc Natl Acad Sci U S A. 2008;105:19060-5.

3. Nathan R, Giuggioli L. A milestone for movement ecology research. Mov Ecol. 2013;1:1.

4. Johnson AR, Wiens JA, Milne BT, Crist TO. Animal movements and population dynamics in heterogeneous landscapes. Landsc Ecol. 1992;7:63-75.

5. Morales JM, Moorcroft PR, Matthiopoulos J, Frair JL, Kie JG, Powell RA, Merrill EH, Haydon DT. Building the bridge between animal movement and population dynamics. Philos Trans R Soc B Biol Sci. 2010;365:2289-301.

6. Mitchell WA, Lima SL. Predator-prey shell games: large-scale movement and its implications for decision-making by prey. Oikos. 2002;99:249-59.

7. Kauffman MJ, Varley N, Smith DW, Stahler DR, MacNulty DR, Boyce MS. Landscape heterogeneity shapes predation in a newly restored predator-prey system. Ecol Lett. 2007;10:690-700.

8. Coulon A, Cosson JF, Angibault JM, Cargnelutti B, Galan M, Morellet N, Petit E, Aulagnier S, Hewison AJM. Landscape connectivity influences gene flow in a roe deer population inhabiting a fragmented landscape: an individual-based approach. Mol Ecol. 2004;13:2841-50.

9. Cushman SA, Lewis JS. Movement behavior explains genetic differentiation in American black bears. Landsc Ecol. 2010;25:1613-25.

10. Van Moorter B, Bunnefeld N, Panzacchi M, Rolandsen CM, Solberg EJ, Sæther B-E. Understanding scales of movement: Animals ride waves and ripples of environmental change. J Anim Ecol. 2013;82:770-80.

11. Fahrig L. Non-optimal animal movement in human-altered landscapes. Funct Ecol. 2007;21:1003-15.

12. Schloss CA, Nuñez TA, Lawler JJ. Dispersal will limit ability of mammals to track climate change in the Western Hemisphere. Proc Natl Acad Sci U S A. 2012;109:8606-11.

13. Travis JMJ, Delgado M, Bocedi G, Baguette M, Bartoń K, Bonte D, Boulangeat I, Hodgson JA, Kubisch A, Penteriani V, Saastamoinen M, Stevens VM, Bullock JM. Dispersal and species' responses to climate change. Oikos. 2013;122:1532-40.

14. Crooks KR, Sanjayan M. Connectivity conservation: maintaining connections for nature. In: Crooks KR, Sanjayan M, editors. Connectivity Conservation. Cambridge: Cambridge University Press; 2006. p. 1-20. 
15. Hilty JA, Lidicker Jr WZ, Merenlender AM. Corridor Ecology: The Science and Practice of Linking Landscapes for Biodiversity Conservation. Washington DC: Island Press; 2006.

16. Rudnick DA, Ryan SJ, Beier P, Cushman SA, Dieffenbach F, Epps CW, Gerber LR, Hartter J, Jenness JS, Kintsch J, Merenlender AM, Perkl RM, Preziosi D V., Trombulak SC. The Role of Landscape Connectivity in Planning and Implementing Conservation and Restoration Priorities. Issues Ecol. 2012;16:1-20.

17. Tischendorf L, Fahrig L. On the usage and measurement of landscape connectivity. Oikos. 2000;90:7-19.

18. Baguette M, Van Dyck H. Landscape connectivity and animal behavior: functional grain as a key determinant for dispersal. Landsc Ecol. 2007;22:1117-29.

19. Laffan SW, Skidmore AK, Franklin J. Space, time, connectivity and conflict in biological landscapes: the fourth special issue on spatial ecology. Int J Geogr Inf Sci. 2016;30:1-4.

20. Goetz SJ, Jantz P, Jantz CA. Connectivity of core habitat in the Northeastern United States: Parks and protected areas in a landscape context. Remote Sens Environ. 2009;113:1421-9.

21. Mazaris AD, Papanikolaou AD, Barbet-Massin M, Kallimanis AS, Jiguet $F$, Schmeller DS, Pantis JD. Evaluating the Connectivity of a Protected Areas' Network under the Prism of Global Change: The Efficiency of the European Natura 2000 Network for Four Birds of Prey. PLoS One. 2013;8, e59640.

22. Wegmann M, Santini L, Leutner B, Safi K, Rocchini D, Bevanda M, Latifi H, Dech S, Rondinini C. Role of African protected areas in maintaining connectivity for large mammals. Philos Trans R Soc Lond B Biol Sci. 2014;369:20130193.

23. Fancy SG, Pank LF, Whitten KR, Regelin WL. Seasonal movements of caribou in artic Alaska as determined by satellite. Can J Zool. 1989;67:644-50.

24. Joly K, Cameron MD. Caribou Vital Sign Annual Report for the Arctic Network Inventory and Monitoring Program: September 2014-August 2015. Natural Resource Report NPS/ARCN/NRR-2015/1090. Fort Collins: National Park Service; 2015

25. Dau J. Units 21D, 22A, 22B, 22C, 22D, 22E, 23, 24, and 26A caribou management report. In: Harper $\mathrm{P}$, editor. Caribou management report of survey and inventory activities 1 July 2008-30 June 2010. Juneau: Alaska Department of Fish and Game; 2011. p. 187-250.

26. Joly K. Sea ice crossing by migrating Caribou, Rangifer tarandus, in northwestern Alaska. Can Field-Naturalist. 2012;126:217-20.

27. Joly K, Bente P, Dau J. Response of Overwintering Caribou to Burned Habitat in Northwest Alaska. Arctic. 2007:60:401-10.

28. Dau J. Units 21D, 22A, 22B, 22C, 22D, 22E, 23, 24, and 26A caribou management report. In: Harper $\mathrm{P}$, editor. Caribou management report of survey and inventory activities 1 July 2010-30 June 2012. Juneau: Alaska Department of Fish and Game; 2013. p. 201-80.

29. Bråthen KA, Ims RA, Yoccoz NG, Fauchald P, Tveraa T, Hausner VH. Induced shift in ecosystem productivity? Extensive scale effects of abundant large herbivores. Ecosystems. 2007;10:773-89.

30. Reynolds III HV, Garner GW. Patterns of Grizzly Bear Predation on Caribou in Northern Alaska. Int Conf Bear Res Manag. 1987;7:59-67.

31. Dale BW, Adams LG, Bowyer RT. Functional response of wolves preying on barren-ground caribou in a multiple-prey ecosystem. J Anim Ecol. 1994;63:644-52.

32. Ballard WB, Ayres LA, Krausman PR, Reed DJ, Fancy SG. Ecology of Wolves in Relation to a Migratory Caribou Herd in Northwest Alaska. Wildl Monogr. 1997; 135:3-47

33. Mowat G, Heard DC. Major components of grizzly bear diet across North America. Can J Zool. 2006;84:473-89.

34. Berkes F, George PJ, Preston RJ, Hughes A, Turner J, Cummins BD. Wildlife Harvesting and Sustainable Regional Native Economy in the Hudson and James Bay Lowland, Ontario. Arctic. 1994;47:350-60.

35. Festa-Bianchet M, Ray JC, Boutin S, Côté SD, Gunn A. Conservation of caribou (Rangifer tarandus) in Canada: an uncertain future. Can J Zool. 2011;89:419-34.

36. Braem NM. Subsistence Wildlife Harvests in Ambler, Buckland, Kiana, Kobuk Shaktoolik and Shishmaref, Alaska, 2009-2010. Special Publication No. SP2012-003. Fairbanks: Alaska Department of Fish and Game Division of Subsistence; 2012

37. Fix PJ, Ackerman A. Noatak National Preserve Sport Hunter Survey: Caribou Hunters from 2010-2013. Natural Resource Report NPS/NOAT/NRR-2015/1005. Fort Collins: National Park Service; 2015.

38. Fix PJ, Harrington AM. Measuring Motivations as a Method of Mitigating Social Values Conflict. Hum Dimens Wildl. 2012;17:367-75.

39. Georgette S, Loon H. The Noatak River: Fall Caribou Hunting and Airplane Use. Technical Paper No. 162. Kotzebue: Alaska Department of Fish and Game, Division of Subsistence; 1988.
40. Calef GW, DeBock EA, Lortie GM. The reaction of barren-ground caribou to aircraft. Arctic. 1976;29:201-12

41. Wolfe SA, Griffith B, Wolfe CAG. Response of reindeer and caribou to human activities. Polar Res. 2000;19:63-73.

42. Halas G. Caribou migration, subsistence hunting, and user group conflicts in northwest Alaska: a traditional knowledge perspective. Thesis. Fairbanks: University of Alaska Fairbanks; 2015.

43. Jacobson C. Fall Hunting in Game Management Unit 23: Assessment of Issues and Proposal for a Planning Process. Juneau: Alaska Department of Fish and Game, Division of Wildlife Conservation; 2008.

44. Adriaensen F, Chardon JP, De Blust G, Swinnen E, Villalba S, Gulinck H, Matthysen E. The application of "least-cost" modelling as a functional landscape model. Landsc Urban Plan. 2003;64:233-47.

45. McRae BH, Dickson BG, Keitt TH, Shah VB. Using circuit theory to model connectivity in ecology, evolution, and conservation. Ecology. 2008:89:2712-24.

46. Doerr VAJ, Barrett T, Doerr ED. Connectivity, dispersal behaviour and conservation under climate change: A response to Hodgson et al. J Appl Ecol. 2011;48:143-7.

47. Poor EE, Loucks C, Jakes A, Urban DL. Comparing Habitat Suitability and Connectivity Modeling Methods for Conserving Pronghorn Migrations. PLoS One. 2012;7, e49390.

48. Koen EL, Bowman J, Sadowski C, Walpole AA. Landscape connectivity for wildlife: Development and validation of multispecies linkage maps. Methods Ecol Evol. 2014;5:626-33.

49. Bishop-Taylor R, Tulbure MG, Broich M. Surface water network structure, landscape resistance to movement and flooding vital for maintaining ecological connectivity across Australia's largest river basin. Landsc Ecol. 2015;30:2045-65.

50. Palmer SCF, Coulon A, Travis JMJ. Introducing a "stochastic movement simulator" for estimating habitat connectivity. Methods Ecol Evol. 2011;2:258-68.

51. Sawyer SC, Epps CW, Brashares JS. Placing linkages among fragmented habitats: Do least-cost models reflect how animals use landscapes? J Appl Ecol. 2011;48:668-78.

52. Coulon A, Aben J, Palmer SCF, Stevens VM, Callens T, Strubbe D, Lens L, Matthysen E, Baguette M, Travis JMJ. A stochastic movement simulator improves estimates of landscape connectivity. Ecology. 2015:96:2203-13.

53. Panzacchi M, Van Moorter B, Strand O, Saerens M, Kivimäki I, St Clair CC, Herfindal I, Boitani L. Predicting the continuum between corridors and barriers to animal movements using Step Selection Functions and Randomized Shortest Paths. J Anim Ecol. 2016;85:32-42.

54. McClure ML, Hansen AJ, Inman RM. Connecting models to movements: testing connectivity model predictions against empirical migration and dispersal data. Landsc Ecol. 2016;31:1419-32.

55. National Park Service. Noatak National Preserve Foundation Statement. Denver: National Park Service Western Arctic National Parklands, Alaska Regional Office; 2009

56. Cotton S. Update: July survey suggests Western Arctic Caribou Herd decline is leveling out. Alaska Department of Fish and Game. 2016. http://www. adfg.alaska.gov/index.cfm?adfg=pressreleases.pr08292016. Accessed 19 Jan 2017

57. Dau JR. Units 21D, 22A, 22B, 22C, 22D, 22E, 23, 24 and 26A. In: Harper P, McCarthy LA, editors. Caribou management report of survey and inventory activities 1 July 2012-30 June 2014. Juneau: Alaska Department of Fish and Game; 2015. p. 14-1-89.

58. Koen EL, Garroway CJ, Wilson PJ, Bowman J. The effect of map boundary on estimates of landscape resistance to animal movement. PLoS One. 2010;5, e11785.

59. Joly K. Modeling influences on winter distribution of caribou in northwestern Alaska through use of satellite telemetry. Rangifer. 2011;19:75-85.

60. Creel S, Christianson D. Relationships between direct predation and risk effects. Trends Ecol Evol. 2008;23:194-201.

61. Kays R, Parsons AW, Baker MC, Kalies EL, Forrester T, Costello R, Rota CT, Millspaugh JJ, MCShea WJ. Does hunting or hiking affect wildlife communities in protected areas? J Appl Ecol. 2017:54:242-52.

62. Plante S, Dussault C, Côté SD. Landscape attributes explain migratory caribou vulnerability to sport hunting. J Wildl Manage. 2017:81:238-47.

63. van Winkle W. Comparison of Several Probabilistic Home-Range Models. J Wild Manage. 1975:39:118-23.

64. Millspaugh JJ, Nielson RM, McDonald L, Marzluff JM, Gitzen RA, Rittenhouse CD, Hubbard MW, Sheriff SL. Analysis of resource selection using utilization distributions. J Wildl Manage. 2006;70:384-95. 
65. R Core Team. R: A language and environment for statistical computing. Vienna: R Foundation for Statistical Computing; 2014. https://www.R-project.org/.

66. Calenge $\mathrm{C}$. The package "adehabitat" for the R software: A tool for the analysis of space and habitat use by animals. Ecol Modell. 2006;197:516-9.

67. Kie JG. A rule-based ad hoc method for selecting a bandwidth in kernel home-range analyses. Anim Biotelemetry. 2013;1:13.

68. Fancy SG, White RG. Energy expenditures for locomotion by barren-ground caribou. Can J Zool. 1987;65:122-8.

69. Wilson RP, Griffiths IW, Legg PA, Friswell MI, Bidder OR, Halsey LG, Lambertucci SA, Shepard ELC. Turn costs change the value of animal search paths. Ecol Lett. 2013;16:1145-50.

70. Wilson RR, Gustine DD, Joly K. Evaluating potential effects of an industrial road on winter habitat of caribou in north-central Alaska. Arctic. 2014;67:472-82.

71. Nellemann C, Thomsen MG. Terrain ruggedness and caribou forage availability during snowmelt on the Arctic Coastal Plain, Alaska. Arctic. 1994;47:361-7.

72. Nellemann C, Fry G. Quantitative analysis of terrain ruggedness in reindeer winter grounds. Arctic. 1995;48:172-6.

73. Sappington JM, Longshore KM, Thompson DB. Quantifying Landscape Ruggedness for Animal Habitat Analysis: A Case Study Using Bighorn Sheep in the Mojave Desert. J Wildl Manage. 2007;71:1419-26.

74. Gesch DB. The National Elevation Dataset. In: Maune D, editor. Digital elevation model technologies and applications: the DEM user's manual. Maryland: American Society for Photogrammetry and Remote Sensing; 2007. p. 99-118.

75. VRM: Vector Ruggedness Measure (Terrain Ruggedness) tool. 2012. http:// www.arcgis.com/home/item.html?id=9e4210b3ee7b413bbb1f98fb9c5b22d4. Accessed 22 June 2015.

76. Williams TM, Gunn A. Descriptions of Water Crossings and Their Use by Migratory Barren-Ground Caribou in the Districts of Keewatin and Mackenzi, N.W.T. Yellowknife: Northwest Territories Wildlife Service; 1982.

77. U.S. Geological Survey. National Hydrography Geodatabase: The National Map Viewer. 2013. http://viewer.nationalmap.gov/viewer/nhd.html?p=nhd. Accessed Oct 2014.

78. Boggs K, Boucher TV, Kuo TT, Fehringer D, Guyer S. Vegetation Map and Classification: Northern, Western and Interior Alaska. Anchorage: Alaska Natural Heritage Program, University of Alaska Anchorage; 2014. http://accs. uaa.alaska.edu/vegetation-ecology/vegetation-map-northern-western-andinterior-alaska/. Accessed Oct 2014.

79. Lechner AM, Langford WT, Jones SD, Bekessy SA, Gordon A. Investigating species-environment relationships at multiple scales: Differentiating between intrinsic scale and the modifiable areal unit problem. Ecol Complex. 2012;11:91-102

80. Bissonette JA. Avoiding the scale sampling problem: A consilient solution. J Wildl Manage. 2017;81:192-205.

81. Beyer HL, Haydon DT, Morales JM, Frair JL, Hebblewhite M, Mitchell M Matthiopoulos J. The interpretation of habitat preference metrics under use-availability designs. Philos Trans R Soc B Biol Sci. 2010;365:2245-54.

82. Zeller KA, McGarigal K, Whiteley AR. Estimating landscape resistance to movement: a review. Landsc Ecol. 2012:27:777-97.

83. Forester JD, Im HK, Rathouz PJ. Accounting for animal movement in estimation of resource selection functions: sampling and data analysis. Ecology. 2009;90:3554-65.

84. Gelman A. Scaling regression inputs by dividing by two standard deviations. Stat Med. 2008:27:2865-73

85. Zuur AF, leno EN, Elphick CS. A protocol for data exploration to avoid common statistical problems. Methods Ecol Evol. 2010;1:3-14

86. Dormann CF, Elith J, Bacher S, Buchmann C, Carl G, Carré G, Marquéz JRG, Gruber B, Lafourcade B, Leitão PJ, Münkemüller T, Mcclean C, Osborne PE, Reineking B, Schröder B, Skidmore AK, Zurell D, Lautenbach S. Collinearity: A review of methods to deal with it and a simulation study evaluating their performance. Ecography. 2013;36:27-46.

87. Therneau T. A package for survival analysis in S. 2015. R package version 2. 38. http://CRAN.R-project.org/package=survival. Accessed July 2015.

88. Therneau TM, Grambsch PM. Modeling Survival Data: Extending the Cox Model. New York: Springer; 2000.

89. Burnham KP, Anderson DR. Model Selection and Multimodel Inference: A Practical Information-Theoretic Approach. 2nd ed. New York: Springer-Verlag New York, Inc.; 2002

90. Boyce MS, Vernier PR, Nielsen SE, Schmiegelow FKA. Evaluating resource selection functions. Ecol Modell. 2002;157:281-300.
91. Johnson CJ, Nielson SE, Merrill EH, McDonald TL, Boyce MS. Resource selection functions based on use-availability data: theoretical motivation and evaluation methods. J Wildl Manage. 2006;70:347-57.

92. Nielson RM, Sawyer H, McDonald TL. BBMM: Brownian bridge movement model. 2013. R package version 3.0. http://CRAN.R-project.org/package= BBMM. Accessed July 2015.

93. Horne JS, Garton EO, Krone SM, Lewis JS. Analyzing Animal Movements Using Brownian Bridges. Ecology. 2007;88:2354-63.

94. Sawyer H, Kauffman MJ, Nielson RM, Horne JS. Identifying and prioritizing ungulate migration routes for landscape-level conservation. Ecol Appl. 2009:19:2016-25.

95. Joly K. The effects of sampling regime on the analysis of movements of overwintering female caribou in east-central Alaska. Rangifer. 2005;25:67-74.

96. Arnold TW. Uninformative parameters and model selection using Akaike's information criterion. J Wildl Manage. 2010;74:1175-8.

97. Johnson CJ, Boyce MS, Ray CL, Cluff DH, Gau RJ, Gunn A, Mulders R. Cumulative effects of human developments on arctic wildlife. Wild Monogr 2005;160:1-36

98. Anderson DD. A Stone Age Campsite at the Gateway to America. Sci Am. 1968:318:24-33.

99. Bradshaw CJA. An Assessment of the Effects of Petroleum Exploration on Woodland Caribou (Rangifer tarandus caribou) in Northeastern Alberta. Edmonton: University of Alberta; 1994.

100. Bradshaw CJA, Boutin S, Hebert DM. Effects of Petroleum Exploration on Woodland Caribou in Northeastern Alberta. J Wildl Manage. 1997;61:1127-33.

101. Bradshaw CJA, Boutin S, Hebert DM. Energetic implications of disturbance caused by petroleum exploration to woodland caribou. Can J Zool. 1998;76:1319-24

102. Wilson RR, Parrett LS, Joly K, Dau JR. Effects of roads on individual caribou movements during migration. Biol Conserv. 2016;195:2-8.

103. Comiso JC, Hall DK. Climate trends in the Arctic as observed from space. Wiley Interdiscip Rev Clim Chang. 2014;5:389-409.

104. Bergerud AT. The reproductive season of Newfoundland caribou. Can J Zool. $1975 ; 53: 1213-21$

105. Cameron RD, Smith WT, Fancy SG, Gerhart KL, White RG. Calving success of female caribou in relation to body weight. Can J Zool. 1993;71:480-6.

106. Long RA, Bowyer RT, Porter WP, Mathewson P, Monteith KL, Findholt SL, Dick BL, Kie JG. Linking habitat selection to fitness-related traits in herbivores: the role of the energy landscape. Oecologia. 2016;181:709-20.

107. Kaufman DS, Schneider DP, McKay NP, Ammann CM, Bradley RS, Briffa KR, Miller GH, Otto-Bliesner BL, Overpeck JT, Vinther BM. Arctic Lakes 2k Project Members. Recent Warming Reverses Long-Term Arctic Cooling. Science. 2009;325:1236-9.

108. Bieniek PA, Walsh JE, Thoman RL, Bhatt US. Using climate divisions to analyze variations and trends in Alaska temperature and precipitation. J Clim. 2014:27:2800-18

109. Xu L, Myneni RB, Chapin III FS, Callaghan TV, Pinzon JE, Tucker CJ, Zhu Z, Bi J, Ciais P, Tømmervik H, Euskirchen ES, Forbes BC, Piao SL, Anderson BT, Ganguly S, Nemani RR, Goetz SJ, Beck PSA, Bunn AG, Cao C, Stroeve JC. Temperature and vegetation seasonality diminishment over northern lands. Nat Clim Chang. 2013;3:581-6.

110. Heard DC, Williams TM, Melton DA. The relationship between food intake and predation risk in migratory caribou and implications to caribou and wolf population dynamics. Rangifer. 1996;2:37-44.

111. Bergerud AT, Luttich SN. Predation risk and optimal foraging trade-off in the demography and spacing of the George River Herd, 1958 to 1993. Rangifer. 2003;14:169-91.

112. Bergman CM, Schaefer JA, Luttich SN. Caribou movement as a correlated random walk. Oecologia. 2000:123:364-74. 